\title{
Product availability from delivery aspect - evidence from retailers in selected Western Balkan countries
}

Article history:

Received: 20 January 2016

Sent for revision: 26 January 2016

Received in revised form: 3 May 2016

Accepted: 6 May 2016

Available online: 11 July 2016

\begin{abstract}
Bearing in mind that it represents one of the main preconditions of sales, product availability is the key task of retail companies and their delivery systems. This paper analyses its levels from the aspect of centralized and DSD systems. The research is conducted in Serbia, Bosnia and Herzegovina and Montenegro, including 84 stores and more than 70 FMCG products per each store. Thereby, the comparisons in product availability levels between alternative delivery systems are carried out within different trading formats and within different product categories. Unlike the results of similar studies and ongoing changes on retail markets, this research shows that at retailers in these Western Balkan countries, availability levels are higher in the case of DSD system.
\end{abstract}

Keywords: product availability, retail, delivery, distribution center, retail formats.

\section{Dostupnost proizvoda sa aspekta isporuke - primer maloprodavaca iz odabranih zemalja Zapadnog Balkana}

Apstrakt: Budući da predstavlja osnovni preduslov za realizaciju prodaje, dostupnost proizvoda je jedan od primarnih zadataka maloprodajnih preduzeća i njihovih sistema isporuke. $U$ radu su analizirani njeni nivoi sa aspekta primene centralizovanih i direktnih sistema isporuke. Istraživanje je sprovedeno u Srbiji, Bosni i Hercegovini i Crnoj Gori, uključujući 84 objekta sa više od 70 proizvoda svakodnevne potrošnje po svakom objektu. Pri tome,

\footnotetext{
${ }^{1}$ University of Novi Sad, Faculty of Economics Subotica

${ }^{2}$ University of Novi Sad, Faculty of Economics Subotica, milicevic.nikola@ef.uns.ac.rs
} 
Grubor A., Milićević N.: Product availability from delivery aspect-evidence from...

komparacije u nivoima dostupnosti između alternativnih sistema isporuke su izvršene u okviru različitih maloprodajnih formata i u okviru različitih kategorija proizvoda. Suprotno rezultatima sličnih studija $i$ promenama na maloprodajnim tržištima, dato istraživanje pokazuje da su nivoi dostupnosti proizvoda kod analiziranih maloprodavaca u odabranim zemljama Zapadnog Balkana viši u slučaju direktne isporuke.

Ključne reči: dostupnost proizvoda, maloprodaja, isporuka, distributivni centar, maloprodajni formati.

\section{Introduction}

In the modern business conditions, retail companies are confronted with increased competition through both traditional and nontraditional channels (Ganesan, George, Jap, Palmatier \& Weitz, 2009). On the other hand, more informed and thus more demanding customers make additional pressure on their market positions, striving for higher service levels.

In order to satisfy the demands of different stakeholders, retailers have implemented new policies and improved their business processes and operations. In Europe, large retail chains make significant investments in technological and non-technological innovations. While the first include technology systems, such as self-scanning, loyalty marketing systems, mobile web platforms and new payment methods, the former are related to the introduction of new in-store merchandising techniques, new customer service approaches and new trading formats (Reynolds \& Cuthbertson, 2014). According to the report of European Commission (2014), in European Union, the sales area of hypermarkets, supermarkets, and discount stores increased by $46 \%, 26 \%$ and $81 \%$ respectively, between 2000 and 2011 . Therefore, in developed EU countries (such as Germany, France and Great Britain), the share of modern trading formats in grocery sales amounts to more than $80 \%$ (Planet Retail, 2014), which represents the contemporary example of generalizing specific organizational innovation in the whole sector. These changes, followed by the globalization process and the development of private labels, have led to the increase of concentration level and retailers' influence in marketing channels. The market share of top five grocery retailers exceeds $60 \%$ in 13 European Union member states, representing $52.8 \%$ of the EU population (European Commission, 2014).

Although retail industry in most Western Balkan countries (WBC) lags significantly behind the developed ones, certain improvements occur on these markets as well. The share of modern trading formats and the level of concentration have increased both in the past decade. According to FAO (2009) in WBC, some retailers have developed a mix of formats including 
Grubor A., Milićević N.: Product availability from delivery aspect-evidence from...

hypermarkets, while at the regional level, the consolidation process, i.e. the expanding of regional chains into smaller markets, is taking place. For example, in the Republic of Serbia, even it is still much lower compared to Western European countries, the percentage of modern formats in grocery sales has been increased from 23\% in 2006 (Lovreta, 2009) to 40\% in 2013 (Lovreta, 2013). Also, after Croatia's Agrokor Group has taken over Slovenian retail chain Mercator (Cerni, 2014), the concentration level increased not only in Serbia, but in Bosnia and Herzegovina as well.

However, despite all changes in retail industry, poor product availability, i.e. the out-of-stock (OOS) still remains a key challenge for all retailers (Grant \& Fernie, 2008), costing them at least $5 \%$ of sales decrease (Oliver Wyman, 2012). Bearing in mind that for European consumers it represents the third most important issue, just after the desire for shorter lines at the cash register and more promotions (Roland Berger Consultants, 2003), the OOS event results in customer dissatisfaction as well (Fernie, Sparks \& McKinnon, 2010). So, besides direct sales losses it can also cause long-term negative effects, such as the decrease of store equity and operational inefficiencies (Ehrenthal, Gruen \& Hofstetter, 2014).

The out-of-stock problem did not bypass the largest retail systems either. WalMart's executives reported that, due to out-of-stocks, company was leaving almost 3 billion dollars on the table (Rosenblum, 2014). In United Kingdom, grocery retailer J. Sainsbury, at which OOS was the greatest source of consumer dissatisfaction (Fernie \& Sparks 2009), had to spend around 200 million pounds to overcome stock-out problems (Bawden, 2005). In addition to retailers, out-of-stocks negatively affect manufacturers, causing loss of sales, brand loyalty and brand equity (Ehrenthal et al., 2014).

As practically, out-of-stock remains an issue academically as well (Fernie et al., 2010; Aastrup \& Kotzab, 2010). In first papers the attention was dedicated to consumer responses in OOS situations (Peckham, 1963; Walter \& Grabner, 1975). Later, the emphasis was on its main root causes (McKinnon, Mendes \& Nabateh, 2007; Fernie \& Grant, 2008; Ehrenthal \& Stölzle, 2013), especially bearing in mind that, despite years of research (Aastrup \& Kotzab, 2010), it continued to pose problems for all supply chain members (Gruen, Corsten \& Bharadwaj, 2002; Anderson, Fitzsimons \& Simester, 2006; Gruen \& Corsten, 2007; Musalem, Olivares, Bradlow, Terwiesch \& Corsten, 2010; Ehrenthal et al., 2014). In this regard, several authors (Stolzle \& Placzek, 2004; Angerer, 2005; Aastrup \& Kotzab, 2009; Grubor \& Milicevic, 2015) have analyzed the OOS problem from the aspects of product and/or store characteristics. However, only few studies investigated out-of-stock levels in the context of different delivery systems (direct and centralized). Moreover, their results were rather contradictory. 
Grubor A., Milićević N.: Product availability from delivery aspect-evidence from...

Starting from this, to our knowledge, we are the first one who analyzed the difference in out-of-stock rates between two delivery systems at retailers in three Western Balkan countries: Republic of Serbia, Bosnia and Herzegovina and Montenegro. These differences were also investigated within different retail formats and within different FMCG product categories. In the following sections we presented main characteristics of both direct and centralized delivery systems, as well as their relations with product availability levels. Sample, data and methods used for calculating OOS rates were described in methodology section, which is followed by results and conclusions.

\section{Centralized and direct store delivery}

Changes in retail, in the form of increasing the concentration, modernization and internationalization levels of business operations have affected the strengthening the market power of retailers, who are taking over the leading role in marketing channels from the manufacturers. According to Lovreta, Petkovic \& Koncar (2006), the change in the balance of powers in favour of retailers is manifested in the rapid growth of total assets, turnover and profitability of large retail chains, especially in the FMCG sector. Dominant retailers are becoming less dependent on manufacturers, which increases their pricing power (Dong, Shankar \& Dresner, 2007). Therefore, large retail companies (such as Wal-Mart) minimize or even eliminate price negotiations with suppliers (Bradley \& Ghemawat, 1994).

The growing power of retail companies is also reflected in the logistics sector. According to Trautrims (2011), higher level of market concentration has enabled retailers to take control over product flows from suppliers, forcing them to adjust their deliveries to current demand rather than to their production plans. Thereby, from passive recipients of products, they have become the controllers of product supply in reaction to known consumer demand (Fernie et al., 2010).

According to McKinnon (1996), this retail logistics transformation is related to the development of centralized delivery systems. Large retail chains have centralized their supplies by using their own distribution centers (DCs). Through DCs, they consolidate deliveries from suppliers for onward delivery to stores (Fernie et al., 2010). In this way, besides increasing control over secondary distribution (from warehouse to store), they can reduce inventory levels and improve their business efficiency (McKinnon, 1996; Pramatari \& Miliotis, 2008; Fernie et al., 2010).

Following Pramatari and Miliotis (2008), a degree of centralization is maintained from 50 percent to more than 90 percent, whereby in the United Kingdom (UK) and Central Europe, 80-95 percent of products are delivered 
Grubor A., Milićević N.: Product availability from delivery aspect-evidence from...

via distribution centers (Kaipia \& Tanskanen, 2003, 169). In addition, in developed European countries, retailers' distribution centers are usually equipped with modern information technology and business systems. In this regard, Harrison and van Hoek (2008) stood out Tesco's centralized system. The UK's largest food retailer uses composite distribution centers, whose warehouse buildings comprise more than 25.000 square meters divided into three temperature zones: frozen $(-250 \mathrm{C})$, chilled $(+10 \mathrm{C})$ and semi-ambient $(+120 \mathrm{C})$. For delivering products that require special storage or handling conditions, Tesco uses vehicles with trailers also divided into different temperature chambers. Each DC serves a group of between 100 and 140 retail stores, handling over 60 million cases per year on a 15-acre site. Through "Tesco Information Exchange system" (TIE), composite distribution centers are connected with retail stores and suppliers, which represents the basis for the adoption of "Quick Response" (QR) strategy. Sales of each product are recorded at the tills, and these data are used in replenishment process. Thus, when inventory drops below the certain level, the order is automatically forwarded from store to distribution center. Bearing in mind that under the auspices of "Efficient Consumer Response", Tesco and other large UK retailers collaborate closely with their suppliers, shorter lead times and frequent deliveries of smaller consignments characterize not only internal product flows between DC and store, but also external product flows between supplier and DC (Fernie et al., 2010). However, despite these advantages, in centralized systems where ordering and other DC operations mostly depend on store personnel, problems concerning lower order accuracy may occur (Pramatari \& Miliotis, 2008).

In addition to centralized delivery, large FMCG retailers, in agreement with their suppliers, may also adopt direct store delivery systems (DSD). Furthermore, unlike centralized systems, the product flow from suppliers to retail stores in direct delivery is not interrupted at the retailer's distribution centre or warehouse. According to Wulfraat (2014), direct store delivery system includes all store deliveries that bypass retailers' DCs. The same author (2014) differentiates 2-tier and 3-tier DSD networks. While in the 2-tier network, products are distributed to retail stores directly by brand owner (manufacturer), in the 3-tier network, this logistics function is outsourced to a third party (distributor). Direct store delivery system usually prevails in developing countries, because of the fact that in many of them larger share of grocery sales belongs to independent retailers with smaller retail stores.

Within the DSD system, several functions can be realized. Besides delivering products to the store, it may include ordering, warehousing, merchandizing and coordinating activities (Grocery Manufacturers Association, 2011). The way in which they are going to be realized primarily depends on retailersupplier relations. In the case of fully integrated DSD system, brand owner or 
Grubor A., Milićević N.: Product availability from delivery aspect-evidence from...

its distributer participate in all of them, from ordering to replenishing retailer shelves.

The implementation of direct store delivery system can bring certain benefits to both retailers and their suppliers (Dalton \& Mullaly, 2013). The main advantage of this system for retail companies is reflected in the reduction of labor and shipping costs. On the other hand, suppliers may improve operations, such as quality control, replenishment and product traceability, and also get more familiar with store and product mix. The study of Grocery Manufacturers Association, AMR Research \& Clarkston Consulting (2008), which included 37 retailers and 42 suppliers, has shown that direct store delivery system contributed to the acceleration of working capital and the increase of promotional effectiveness. However, bearing in mind that DSD system depends on a supplier in a great extent, its implementation may cause the retailer to lose the control over distribution channel. In addition, Dalton and Mullaly (2013) also include manual product check-ins, large paperwork and order quantity disagreements in main problems of direct store delivery.

In the last few decades, with the change in balance of power in marketing channels, the use of direct delivery system is called into question. Regarding this, in order to reduce inventory assets and overall logistics costs, world leading retailers have started switching away from direct to centralized delivery (Wulfraat, 2014).

\section{Delivery system and product availability}

For both systems, centralized and direct, the main task lies in getting the right product to the right place at the right time (Fernie \& Sparks, 2009). According to Reynolds and Cuthbertson $(2014,55)$, delivering the right mix of products represents a critical competitive advantage for retailers and creates a dynamic and responsive environment for customers. In the FMCG sector, the mentioned task is related to providing an adequate level of on-shelf availability (OSA). Therefore, product availability was investigated in a few studies in the context of these delivery systems.

Regarding the difference between centralized and direct store delivery in a large retail chain, Gruen and Corsten (2007) have found that the former was associated with higher on-shelf availability levels. They see the reason for this in coordination between store deliveries and shelf replenishment operations. Unlike centralized system, in the case of DSD, supplier deliveries were uncoordinated with shelf replenishment routines. In addition to the de-coupling of store and shelf replenishment, direct store delivery also caused problems in implementing store policy. 
Grubor A., Milićević N.: Product availability from delivery aspect-evidence from...

Similar to previous authors, Pramatari and Miliotis (2008) also compared centralized and direct store delivery from the aspect of shelf availability. The results of their field experiment, conducted at the third biggest grocery retailer in Greece, have shown that the overall level of OOS was higher for DSD products. Furthermore, they analyzed the factors of product availability for both systems. While centralized delivery performs better in factors related to logistics efficiency, such as order frequency, lead time and order size, direct store delivery is associated with higher order accuracy.

However, there are researches whose results differ from the previous ones. According to Roland Berger Consultants (2003), delivery method plays a subordinate role with regard to on-shelf availability. Their report pointed to the existence of difference lower than $0.3 \%$ between alternative delivery systems in OOS level. On the other hand, the results of Grocery Manufacturers Association's study (2011), which included 6 product categories in 28 retail stores, have shown that shelf availability of DSD products was higher compared to the average availability level for both DSD and warehouse delivered products found in recent researches.

\section{Research methodology}

This paper analyses shelf availability levels from delivery aspect in three Western Balkan countries: Republic of Serbia, Bosnia and Herzegovina and Montenegro. Thus, our research included 84 retail stores, which were divided into three trading formats depending on the size of sales area and retailers' internal organizational structure: superettes, supermarkets and hypermarkets.

Table 1. Trading formats

\begin{tabular}{|c|c|c|c|c|}
\hline Retail Formats & $\begin{array}{c}\text { Republic of } \\
\text { Serbia }\end{array}$ & $\begin{array}{c}\text { Bosnia and } \\
\text { Herzegovina }\end{array}$ & Montenegro & Total \\
\hline Superettes & 15 & 12 & 10 & 37 \\
\hline Supermarkets & 15 & 12 & 10 & 37 \\
\hline Hypermarkets & 5 & 5 & - & 10 \\
\hline Total & 35 & 29 & 20 & 84 \\
\hline
\end{tabular}

Source: authors' calculations

With the help of supply chain directors, we have chosen from 70 to 80 FMCG products per store. In Serbia and Bosnia and Herzegovina, they have been selected from 11 product categories: personal hygiene care products, household care products, soft drinks, alcoholic drinks, spices and aromas, sugar and products made from sugar, edible oils and fats, cereal-based products and flour, coffee and tea, confectionery products (sweets), and salty 
Grubor A., Milićević N.: Product availability from delivery aspect-evidence from...

snacks. On the other hand, in Montenegro, all products have been taken from 10 FMCG categories (same as in previous countries, except sugar products). Consequently, each category included both products that have been delivered via centralized and products that have been delivered via DSD system.

Following other studies (Roland Berger Consultants, 2003; Ettouzani, Yates \& Mena, 2012), we expressed product availability through its complement outof-stock. For calculating OOS levels, POS sales estimation method was used (Hausruckinger, 2006; Gruen \& Corsten, 2007). Thereby, the out-of-stock rate for product $i$ in the store $s$ has been obtained from the following formula:

$$
\text { OOSis }=\frac{\text { LOST SALES IN UNITS } \text { is }_{\text {STECTED SALES IN UNITS }}}{\text { EXPE }} * 100
$$

ECR Europe presented the approach for calculating the expected sales ranges for each product (Hausruckinger, 2006). However, bearing in mind that this method is problematic for FMCG products with high sales volatility (Papakiriakopoulos, Pramatari \& Doukidis, 2009), following Grubor \& Milicevic (2015), when computing variables in formula (1), we used additional features proposed by Papakiriakopoulos and Doukidis (2011). All necessary data from 2013 (2014), were obtained from retailers' ERP information platforms connected with stores' POS terminals.

After computing OOS levels for each product in each store, we analyzed them in the context of different delivery systems. In this regard, we tested the following hypothesis:

H1: There is significant difference in product availability between products delivered via centralized and products delivered via DSD system.

H2: The difference in product availability between two delivery systems is significant within different retail formats.

H3: The difference in product availability between two delivery systems is significant within different product categories.

Bearing in mind that sample size includes more than 6 thousand observations, we used t-test for proving these hypotheses. Its application is appropriate for comparisons between two independent groups (centralized and DSD) when the dependent variable, i.e. out-of-stock level is continuous.

\section{Results and discussion}

The overall average out-of-stock rate is higher for products delivered via centralized $(3.68 \%)$, contrary to products delivered via DSD system $(2.77 \%)$. Lower average OOS rates for DSD products are recorded at retailers in all 
Grubor A., Milićević N.: Product availability from delivery aspect-evidence from...

three countries, as well. In Serbia, Bosnia and Herzegovina and Montenegro, the average out-of-stock levels of products delivered via distribution centers amount to $5.35 \%, 1.89 \%$ and $3.30 \%$, while their values for products delivered via DSD system are $4.47 \%, 1.23 \%$ and $1.78 \%$, respectively (Figure 1 ).

Figure 1. Average OOS levels - centralized and direct delivery systems

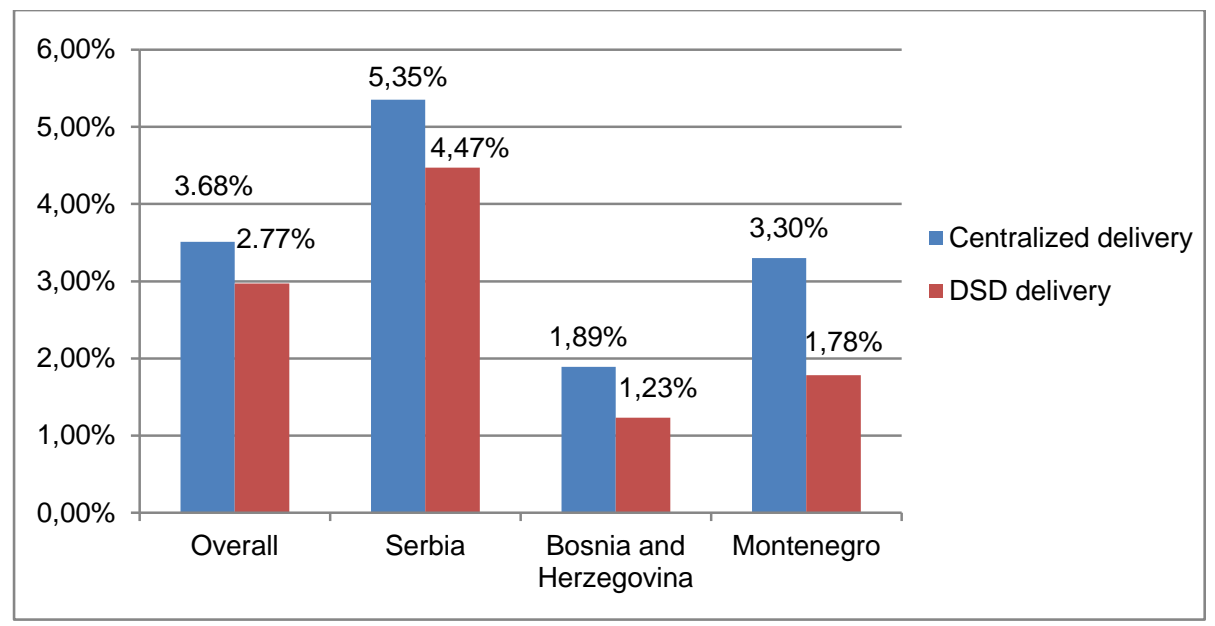

Source: authors' calculations

Differences in out-of-stock rates between alternative delivery systems are analyzed by t-test. Its results are shown in Table 2 .

Table 2. Mean differences in OOS rates between direct and centralized delivery systems (t-test)

\begin{tabular}{|c|c|c|c|c|}
\hline \multirow{2}{*}{ Country } & \multicolumn{4}{|c|}{$\mathrm{t}$-test } \\
\cline { 2 - 5 } & Mean Difference & $\mathrm{t}$ & $\mathrm{df}$ & Sig. \\
\hline Overall & -0.0091 & -5.061 & 6244.62 & $0.000^{\star *}$ \\
\hline Republic of Serbia & -0.0088 & -2.725 & 2732.88 & $0.006^{\star \star}$ \\
\hline Bosnia and Herzegovina & -0.0066 & -3.223 & 1988.87 & $0.001^{\text {}}$ \\
\hline Montenegro & -0.0151 & -4.226 & 1323.97 & $0.000^{\text {** }}$ \\
\hline
\end{tabular}

${ }^{* *} \mathrm{p}<0.05$

Source: authors' calculations

As presented in Table 2, all differences are negative, with $p<0.05$. Thereby, OOS rates are significantly lower in the case of direct store delivery, i.e. the average availability levels of products delivered via DSD system are 
Grubor A., Milićević N.: Product availability from delivery aspect-evidence from...

significantly higher than the average availability levels of products delivered via centralized system, which confirms hypothesis $\mathrm{H} 1$.

Out-of-stock levels of different delivery systems are tested within retail formats and product categories as well. In Serbia and Bosnia and Herzegovina, OOS differences are examined within three (superettes, supermarkets and hypermarkets), and in Montenegro within two trading formats (superettes and supermarkets).

Table 3: Mean differences in OOS rates between direct and centralized delivery systems within different retail formats (t-test)

\begin{tabular}{|c|c|c|c|c|c|c|}
\hline \multirow{3}{*}{ Country } & \multirow{2}{*}{ Retail formats } & \multicolumn{5}{|c|}{ t-test } \\
\cline { 3 - 7 } & $\begin{array}{c}\text { OOS } \\
\text { DSD }\end{array}$ & $\begin{array}{c}\text { OOS } \\
\text { DC }\end{array}$ & $\begin{array}{c}\text { Mean } \\
\text { Diff. }\end{array}$ & $t$ & Sig. \\
\hline \multirow{2}{*}{$\begin{array}{c}\text { Republic of } \\
\text { Serbia }\end{array}$} & Superettes & 0.0616 & 0.0686 & -0.0069 & -1.245 & 0.213 \\
\cline { 2 - 7 } & Supermarkets & 0.0377 & 0.0496 & -0.0118 & -2.639 & $0.008^{* *}$ \\
\cline { 2 - 7 } & Hypermarkets & 0.0175 & 0.0182 & -0.0006 & -0.121 & 0.904 \\
\hline \multirow{3}{*}{$\begin{array}{c}\text { Bosnia and } \\
\text { Herzegovina }\end{array}$} & Superettes & 0.0161 & 0.0244 & -0.0082 & -2.299 & $0.022^{* *}$ \\
\cline { 2 - 7 } & Supermarkets & 0.0099 & 0.0174 & -0.0075 & -2.437 & $0.015^{* *}$ \\
\cline { 2 - 7 } & Hypermarkets & 0.0089 & 0.0110 & -0.0021 & -0.581 & 0.561 \\
\hline \multirow{2}{*}{ Montenegro } & Superettes & 0.0196 & 0.0384 & -0.0188 & -3.419 & $0.001^{* *}$ \\
\cline { 2 - 7 } & Supermarkets & 0.0160 & 0.0277 & -0.0117 & -2.533 & $0.012^{* *}$ \\
\hline
\end{tabular}

${ }^{* *} p<0.05 ;{ }^{*} p<0.1$

Source: authors' calculations

Differences in out-of-stock rates between direct and centralized delivery systems are negative at all retail formats. However, at both hypermarkets (in Bosnia and Herzegovina and Serbia), as well as at superettes in Serbia, this difference is not statistically significant. On the other hand, at all other formats, OOS rates are significantly lower in the case of DSD system. Thereby, at supermarkets in all three countries and at superettes in Bosnia and Herzegovina and Montenegro, negative mean differences are statistically significant with $p<0,05$. Bearing in mind that significant difference is not confirmed at all formats, hypothesis $\mathrm{H} 2$ can be partially accepted. 
Grubor A., Milićević N.: Product availability from delivery aspect-evidence from...

Table 4: Mean differences in OOS rates between direct and centralized delivery systems within different product categories (t-test)

\begin{tabular}{|c|c|c|c|c|c|c|}
\hline \multirow[b]{2}{*}{ Country } & \multirow[b]{2}{*}{ Product Category } & \multicolumn{5}{|c|}{ t-test } \\
\hline & & $\begin{array}{l}\text { OOS } \\
\text { DSD }\end{array}$ & $\begin{array}{l}\text { OOS } \\
\text { DC }\end{array}$ & $\begin{array}{l}\text { Mean } \\
\text { Diff. }\end{array}$ & $\mathrm{t}$ & Sig. \\
\hline \multirow{11}{*}{$\begin{array}{l}\text { Republic of } \\
\text { Serbia }\end{array}$} & Alcoholic drinks & 0.0557 & 0.0997 & -0.0439 & -2.847 & $0.006^{* *}$ \\
\hline & Soft drinks & 0.0129 & 0.0267 & -0.0137 & -2.469 & $0.014^{* *}$ \\
\hline & Flour and cereals & 0.0311 & 0.0305 & 0.0005 & 0.095 & 0.924 \\
\hline & Sugar products & 0.0494 & 0.0946 & -0.0452 & -3.971 & $0.000^{* *}$ \\
\hline & Edible oils & 0.0620 & 0.0142 & 0.0477 & 5.500 & $0.000^{* *}$ \\
\hline & Spices & 0.0446 & 0.0671 & -0.0225 & -2.262 & $0.024^{* *}$ \\
\hline & Salty snacks & 0.0134 & 0.0226 & -0.0092 & -1.675 & $0.097^{*}$ \\
\hline & Coffee and tea & 0.0114 & 0.0132 & -0.0017 & -0.378 & 0.706 \\
\hline & Confectionery & 0.0402 & 0.0477 & -0.0075 & -1.246 & 0.213 \\
\hline & Household care & 0.1507 & 0.1093 & 0.0413 & 2.046 & $0.042^{\star \star}$ \\
\hline & Personal care & 0.0463 & 0.0534 & -0.0071 & -0.537 & 0.592 \\
\hline \multirow{11}{*}{$\begin{array}{l}\text { Bosnia and } \\
\text { Herzegovina }\end{array}$} & Alcoholic drinks & 0.0114 & 0.0348 & -0.0234 & -1.974 & $0.052^{*}$ \\
\hline & Soft drinks & 0.0181 & 0.0182 & -0.0001 & -0.015 & 0.988 \\
\hline & Flour and cereals & 0.0073 & 0.0112 & -0.0039 & -0.969 & 0.333 \\
\hline & Sugar products & 0.0283 & 0.0047 & 0.0235 & 2.510 & $0.014^{* *}$ \\
\hline & Edible oils & 0.0216 & 0.0192 & 0.0024 & 0.273 & 0.785 \\
\hline & Spices & 0.0107 & 0.0253 & -0.0145 & -2.298 & $0.022^{\star *}$ \\
\hline & Salty snacks & 0.0084 & 0.0098 & -0.0014 & -0.270 & 0.788 \\
\hline & Coffee and tea & 0.0111 & 0.0151 & -0.0040 & -0.800 & 0.424 \\
\hline & Confectionery & 0.0091 & 0.0168 & -0.0076 & -1.775 & $0.077^{*}$ \\
\hline & Household care & 0.0157 & 0.0343 & -0.0186 & -2.424 & $0.016^{* *}$ \\
\hline & Personal care & 0.0070 & 0.0301 & -0.0231 & -1.994 & $0.050^{*}$ \\
\hline \multirow{10}{*}{ Montenegro } & Alcoholic drinks & 0.0122 & 0.0259 & -0.0137 & -1.578 & 0.118 \\
\hline & Soft drinks & 0.0306 & 0.0957 & -0.0650 & -4.424 & $0.000^{\star *}$ \\
\hline & Flour and cereals & 0.0300 & 0.0102 & 0.0198 & 2.275 & $0.025^{\star *}$ \\
\hline & Edible oils & 0.0436 & 0.0029 & 0.0407 & 2.651 & $0.011^{* *}$ \\
\hline & Spices & 0.0117 & 0.0286 & -0.0168 & -1.837 & $0.068^{*}$ \\
\hline & Salty snacks & 0.0379 & 0.0570 & -0.0191 & -1.081 & 0.282 \\
\hline & Coffee and tea & 0.0048 & 0.0101 & -0.0053 & -1.186 & 0.241 \\
\hline & Confectionery & 0.0059 & 0.0134 & -0.0074 & -1.782 & $0.077^{\star}$ \\
\hline & Household care & 0.0072 & 0.0373 & -0.0300 & -3.157 & $0.002^{* *}$ \\
\hline & Personal care & 0.0108 & 0.0372 & -0.0264 & -1.843 & $0.069^{*}$ \\
\hline
\end{tabular}

${ }^{* *} p<0,05 ;{ }^{*} p<0,1$.

Source: authors' calculations

Concerning product categories, higher out-of-stock rates are also related to centralized delivery. Thus, significantly higher availability levels with $p<0,05$ 
Grubor A., Milićević N.: Product availability from delivery aspect-evidence from...

for products delivered via DSD system are recorded at four categories in the Republic of Serbia (alcoholic drinks, soft drinks, sugar products, spices and aromas), two categories in Bosnia and Herzegovina (spices and aromas and household care products) and two categories in Montenegro (soft drinks and household care products). In addition, significant negative differences with $p<0,1$, are recorded at salty snacks category in Serbia, three categories in Bosnia and Herzegovina (alcoholic drinks, confectionery and personal hygiene care products) and three categories in Montenegro (spices and aromas, confectionery and personal hygiene care products). Contrary, significantly lower OOS rates for products delivered via distribution centers occur at only two categories in Serbia (edible oils and fats and household care products), one category in Bosnia and Herzegovina (sugar and products made of sugar), and two categories in Montenegro (flour and cereals and edible oils and fats). As there are product categories within which the differences in OOS rates are non significant, hypothesis $\mathrm{H} 3$ is only partially confirmed.

Higher out-of-stock rates in the case of application of centralized delivery systems may be caused by insufficient development of the retailer's distribution centres. Unlike the leading worldwide and European retail chains, whose centralized delivery systems are based on large distribution centres, equipped with contemporary technological and information systems, in the sampled countries, retailers use significantly smaller distribution and storage centres for centralized delivery, where most activities are usually performed manually. In addition, in the absence of automated business systems, the ordering process for centralized deliveries is the responsibility of the store personnel alone (Pramatari \& Miliotis, 2008). Faced with a large number of products, mostly on a daily basis, the employees cannot pay sufficient attention to all products, which often results in errors in the ordering process, and consequently out-of-stock situations.

On the other hand, in the case of direct store delivery, suppliers (distributers) place emphasis on a smaller number of products, better knowing their characteristics, behavior and marketing plans (Pramatari \& Miliotis, 2008). Also, while retailers on the territories of Serbia, Bosnia and Herzegovina and Montenegro do not pay sufficient attention to logistics, distributors invest significant funds in logistic capacities, enhancing the systems, i.e. processes of direct delivery, striving for on-shelf availability of their products on display aisles.

Significantly higher on-shelf availability levels of products directly delivered to stores were established in smaller retail formats (superettes and supermarkets) in almost all countries, and in a significant number of product categories. The absence of statistically significant difference in out-of-stock rates between alternative delivery systems in hypermarkets may be reflected 
Grubor A., Milićević N.: Product availability from delivery aspect-evidence from...

in the significance of these formats for retailers, as well as their location. Due to their significant share in sales, greater attention in organising centralised deliveries is paid to hypermarkets in comparison with smaller stores, i.e. formats, whereas their accessible location greatly facilitate the realisation of transport and other logistic activities. Also, all internal operations in hypermarkets are organized on the principles of category management, with a clear division of obligations and responsibilities among the employees according to certain product categories (Grubor \& Milicevic, 2015). From the aspect of categories, higher product availability levels of products delivered through the retailers' distribution centres were recorded only in particular categories, mostly in staple food products (edible oils and fats, flour and cereal products). As these products are used almost in every household, with a wide application, retailers order them in significantly larger quantities and deliver them to retail stores from distribution centres.

\section{Conclusions}

In order to meet customer needs and survive in the increasingly intensive competitive struggle, retailers are forced to keep enhancing their operations and apply innovative technological and business solutions. With the globalization process, accompanied by numerous market changes, they have taken over the leading role in the marketing channels from the manufacturers. In addition to the developed EU countries, the increase in the level of market concentration and share of contemporary retail formats has not bypassed the Western Balkans countries either.

Changes in the retail sector have made an impact on logistic flows as well. Retailers in developed countries are increasingly centralizing their supply operations, taking control over product flows. Contemporary distribution centres, comprising tens of thousands of square metres, are equipped with sophisticated information systems, through which they are connected not only with retail stores, but also suppliers' storage centres. On the other hand, retailers may also opt for the direct delivery system, thus bypassing retailers' distribution centres, i.e. suppliers directly delivers the products to retail stores. Despite being less represented in developed countries, the application of DSD systems is especially widespread in the Western Balkans countries.

However, despite the fact that the basic aim of both delivery systems is related to product availability, one of the greatest problem faced by even the world's leading retail companies is out-of-stock. In addition to short-term effects in the form of reduced sales, the given situation can also lead to reduced customer loyalty, i.e. reduced brand loyalty, which may have a longterm impact on the operation of retailers and their suppliers (manufacturers). 
Grubor A., Milićević N.: Product availability from delivery aspect-evidence from...

Therefore, in addition to practice, the given problem is studied from several aspects in scientific circles as well. In the context of the application of different delivery systems, alongside the several studies and researches giving preference from the aspect of availability to the centralized system, there are also studies with opposite results.

The results of research that included retailers in the Republic of Serbia, Bosnia and Herzegovina and Montenegro, have shown that availability is far lower for products delivered from the retailer's distribution centre. Significantly higher out-of-stock rates in the case of application of centralised delivery system have been established in supermarkets in all three countries and in superettes in Bosnia and Herzegovina and Montenegro. Also, negative differences in the out-of-stock rates between the direct and the centralised system occur in five categories (alcoholic drinks, soft drinks, sugar products, spices and aromas and salty snacks in Serbia, alcoholic drinks, spices and aromas, confectionery, household care and personal hygiene care products in Bosnia and Herzegovina and at soft drinks, spices and aromas, confectionery, household care and personal hygiene care products in Montenegro). Significant differences have not been established in hypermarkets, whereas significantly higher out-of-stock rates in the case of application of direct delivery system have been recorded in not more than two product categories.

From the managerial aspect, starting from insufficiently developed centralised delivery systems, raising the product availability requires modernisation of the existing and construction of new distribution centres. Despite the fact that it requires high investment, setting up an adequate system of centralised delivery, especially in the conditions of globalization and changes on the retail markets, features as one of the essential prerequisites for increasing the efficiency and effectiveness of retailers' business operation. Implementation of contemporary information technology (RFID) and modern inventory management systems such as pick-to-light (PTL) and pick-to-voice (PTV) systems, are of special importance. Their application enables more efficient identification and monitoring of products and more efficient realization of replenishment and picking operations in warehouses. Also a significant contribution to reducing out-of-stocks, both in centralised and direct delivery systems, can be made by the implementation of automated product ordering systems, with the establishment of closer cooperation with suppliers.

In addition to pointing to higher out-of-stock rates in the case of centralised delivery system, the obtained results have created a basis for certain future research. This can be conducted within each product category, where individual product characteristics may be included, as well as relationships between retailers and suppliers. Also, bearing in mind the relatively small number of sampled products and that retailers are paying more attention to 
Grubor A., Milićević N.: Product availability from delivery aspect-evidence from...

the development of the centralized systems, this research should be repeated in certain time.

\section{References}

Aastrup, J. \& Kotzab, H. (2009). Analyzing out-of-stock in independent grocery stores: An empirical study. International Journal of Retail \& Distribution Management, 37(9), 765-789. http://dx.doi.org/10.1108/09590550910975817

Aastrup, J. \& Kotzab, H. (2010). Forty years of out-of-stock research and shelves are still empty. International Review of Retail, Distribution and Consumer Research, 20(1), 147-164. doi: 10.1080/09593960903498284

Anderson, E., Fitzsimons, G. \& Simester, D. (2006). Measuring and mitigating the costs of stockouts. Management Science, 52(11), 1751-1763. doi: $10.1287 / \mathrm{mnsc} .1060 .0577$

Angerer, A. (2005). The Impact of Automatic Store Replenishment Systems on Retail (PhD thesis, University of St. Gallen). Retrieved from www1.unisg.ch/www/edis.nsf/SysLkpByldentifier/3123/\$FILE/dis3123.pdf

Bawden, T. (2005). Food shortages add to Sainsbury woe, The Times, 7, 52-52.

Bradley, S.P. \& Ghemawat, P. (1994). Wal-Mart stores. Harvard Business School Case No. 9-794-024.

Cerni, B. (2014). Agrokor to buy Mercator in largest takeover in Balkans. Bloomberg Business, Retrived from http://www.bloomberg.com/news/articles/2014-0626/agrokor-to-buy-mercator-in-largest-takeover-in-balkans

Dalton, L. \& Mullaly, B. (2013). All about Direct Store Delivery. Retrived from speakers.uconnectevent.org/2013/finalppt/74_06112013_071922.pdf

Dong, Y., Shankar, V. \& Dresner, M.(2007). Efficient replenishment in the distribution channel. Journal of Retailing, 83(3), 253-278. doi:10.1016/j.jretai.2007.03.003

Ehrenthal, J. \& Stolzle, W. (2013). An examination of the causes for retail stockouts. International Journal of Physical Distribution \& Logistics Management, 43(1), 5469. doi:10.1108/09600031311293255

Ehrenthal, J., Gruen, T. \& Hofstetter, J. (2014). Value attenuation and retail out-ofstocks, a service-dominant logic perspective. International Journal of Physical Distribution \& Logistics Management, 44(1/2), 39-57. doi:10.1108/IJPDLM-022013-0028

Ettouzani, Y., Yates, N. \& Mena, C. (2012). Examining retail on shelf availability: Promotional impact and a call for research. International Journal of Physical Distribution \& Logistics Management, 42(3), 213-243. doi:10.1108/09600031211225945

European Commission. (2014). The economic impact of modern retail on choice and innovation in the EU food sector. Luxembourg: author.

FAO. (2009). Food retail. Rome: author.

Fernie, J. \& Grant, D. (2008). On-shelf availability: the case of a UK grocery retailer. The International Journal of Logistics Management, 19(3), 293-308. doi:10.1108/09574090810919170

Fernie, J. \& Sparks, L. (2009). Logistics and retail management. London: Kogan Page Limited. 
Grubor A., Milićević N.: Product availability from delivery aspect-evidence from...

Fernie, J., Sparks, L. \& McKinnon, A. (2010). Retail logistics in the UK: past, present and future. International Journal of Retail \& Distribution Management, 38(11/12), 894-914. doi:10.1108/09590551011085975

Ganesan, S., George, M., Jap, S., Palmatier, R.W. \& Weitz, B. (2009). Supply chain management and retailer performance: Emerging trends, issues, and implications for research and practice. Journal of Retailing, 85(1), 84-94. doi:10.1016/j.jretai.2008.12.001

Grant, D. \& Fernie, J. (2008). Research note: Exploring out-of-stock and on-shelf availability in non-grocery, high street retailing. International Journal of Retail \& Distribution Management, 36(8), 661-672. doi:10.1108/09590550810883496

Grocery Manufacturers Association. (2011). Optimizing The Value Of Integrated DSD. Washington: author.

Grocery Manufacturers Association, AMR Research \& Clarkston Consulting. (2008). Powering growth through direct store delivery. Washington: author.

Grubor, A. \& Milicevic, N. (2015). The Analysis of fmcg product availability in retail stores. Inzinerine Ekonomika-Engineering Economics, 26(1), 67-74. doi:10.5755/j01.ee.26.1.7070

Gruen, T., Corsten, D. \& Bharadwaj, S. (2002). Retail out-of-stocks: A worldwide examination of extent, causes and consumer responses. Washington: Grocery Manufacturers of America.

Gruen, T. \& Corsten, D. (2007). A comprehensive guide to retail out-of- stock reduction in the fast-moving consumer goods industry. Grocery Manufacturers of America, Food Marketing Institute, National Association of Chain Drug Stores, The Procter \& Gamble Company, University of Colorado at Colorado Springs. Retrived from http://www.nacds.org/pdfs/membership/out_of_stock.pdf

Harrison, A. \& van Hoek, R.I. (2008). Logistics Management and Strategy: Competing Through the Supply Chain. Harlow: Prentice Hall.

Hausruckinger, G. (2006). Approaches to measuring on-shelf availability at the point of sale. ECR Europe. Retrived from http://ecr-all.org/files/OSA-MeasurementWhite-Paper-final_E.pdf

Kaipia, R. \& Tanskanen, K. (2003). Vendor managed category management: an outsourcing solution in retailing. Journal of Purchasing \& Supply Management, 9, 165-175. doi:10.1016/S1478-4092(03)00009-8

Lovreta, S., Petkovic, G. \& Koncar, J. (2006). Kanali marketinga. Belgrade: Faculty of Economics.

Lovreta, S. (2009). Strategija razvoja trgovine Republike Srbije. Belgrade: Faculty of Economics.

Lovreta, S. (2013). Trgovinska revolucija. Progressive magazin, 108, 24-27. Retrived from http://progressivemagazin.rs/online/stipe-lovreta/

McKinnon, A. (1996). The development of retail logistics in the UK. UK technology foresight, retail and distribution panel, a position paper. Heriot-Watt University. Retrived from http://down.cenet.org.cn/upfile/47/200741422455157.pdf

McKinnon, A., Mendes, D. \& Nabateh, M. (2007). In-store logistics: An analysis of onshelf availability and stockout response for three product groups. International Journal of Logistics: Research and Applications, 10(3), 251-268. doi:10.1080/13675560701478075

Musalem, A., Olivares, M., Bradlow, E., Terwiesch, C. \& Corsten, D. (2010). Structural estimation of the effect of out-of-stocks. Management Science, 56(7), 11801197. doi: $10.1287 / \mathrm{mnsc} .1100 .1170$ 
Grubor A., Milićević N.: Product availability from delivery aspect-evidence from...

Oliver Wyman. (2012). Getting availability right: Bringing out of stocks under control. New York: Marsh \& McLennan Companies.

Papakiriakopoulos, D., Pramatari, K. \& Doukidis, G. (2009). A decision support system for detecting products missing from the shelf based on heuristic rules. Decision Support Systems, 46, 685-694. doi:10.1016/j.dss.2008.11.004

Papakiriakopoulos, D. \& Doukidis, G. (2011). Classification performance for making decisions about products missing from the shelf. Advances in Decision Sciences, 1-13. doi:10.1155/2011/515978

Peckham, J. (1963). The consumer speaks. The Journal of Marketing, 27(4), 21-26. Retrived from http://www.jstor.org/stable/1248641

Planet Retail. (2014). European grocery retailing: Change is the only constant. London: Planet Retail.

Pramatari, K. \& Miliotis, P. (2008). The impact of collaborative store ordering on shelf availability. Supply Chain Management: An International Journal, 13(1), 49-61. doi:10.1108/13598540810850319

Reynolds, J. \& Cuthbertson, R. (2014). Retail \& wholesale: Key sectors for the European economy. Oxford: Institute of Retail Management, University of Oxford.

Roland Berger Strategy Consultants. (2003). ECR - Optimal Shelf Availability Increasing Shopper Satisfaction at the moment of truth. ECR Europe. Retrived from http://ecr-all.org/wp-content/uploads/pub_2003_osa_blue_book.pdf

Rosenblum, P. (2014). Walmart's out of stock problem: only half the story? Retrived from http://www.forbes.com/sites/paularosenblum/2014/04/15/walmarts-out-ofstock-problem-only-half-the-story/

Stolzle, W. \& Placzek, T. (2004). Umsetzung von optimal shelf availability messkonzepte und standardisierun-gspotenziale. Germany: BVL congress.

Trautrims, A. (2011). Management of in-store replenishment systems: An exploratory study of european retailers. (PhD thesis, University of Hull). Retrived from https://hydra.hull.ac.uk/assets/hull:4697a/content

Walter, C. K. \& Grabner, J. (1975). Stockout cost models: Empirical tests in a retail situation, Journal of Marketing, 39(3), 56-60. Retrived from http://www.jstor.org/stable/1250902

Wulfraat, M. (2014). Direct store delivery versus centralized distribution. Montreal West, Canada: MWPVL International. 
Grubor A., Milićević N.: Product availability from delivery aspect-evidence from... 